\title{
Features of female reproductive senescence in tamarins (Saguinus spp.), a New World primate
}

\author{
S. D. Tardif ${ }^{1}$ and T. E. Ziegler ${ }^{2}$ \\ ${ }^{1}$ Marmoset Research Center, Oak Ridge Associated Universities, Oak Ridge, TN 37830, USA; and \\ ${ }^{2}$ Department of Psychology, University of Wisconsin, Madison, WI 53706, USA
}

\begin{abstract}
Summary. Cyclical changes in concentration of plasma progesterone, urinary oestroneconjugates and urinary luteinizing hormone $(\mathrm{LH})$ were compared in young and older cotton-top tamarins (Saguinus oedipus) and saddle-backed tamarins (S. fuscicollis). A group of six young adult tamarin females (4-5 years of age) was sampled over eight periods of 6-8 weeks and six older (14-20 years of age) females were sampled over thirteen periods. There was hormonal evidence of ovulation in all of the sampling periods for young females; in five of thirteen periods, older females displayed no evidence of ovulation. Of the six older females, two were anovulatory in one sampling period, while one female displayed no evidence of ovulation in any of three sampling periods. Generally, females over 17 years of age either did not ovulate or displayed abnormally long periods of moderate concentrations of progesterone and oestrone conjugates. Basal concentrations of LH differed in individuals, but were not always higher in older females. In contrast to patterns of reproductive senescence in other primates, older, anovulatory tamarins displayed moderate concentrations of urinary oestrone conjugates $(5-50 \mu \mathrm{g} / \mathrm{mg}$ creatinine) and plasma progesterone $(8-19 \mathrm{ng} / \mathrm{ml})$, both of which are hormones of probable luteal origin in these species. This result suggests continued production of steroids by the luteal cells of the prominent interstitial gland in reproductively senescent tamarins. This suggestion was reinforced by histological examination of the ovaries of four older, anovulatory females; few primary follicles were found. Three females had no normal antral follicles, but all females had large luteal masses. The presence of functional luteal cells in the older ovaries, which do not experience regular follicular development, may distinguish ovarian ageing in New World primates from that of Old World primates.
\end{abstract}

Ke!words: ageing; ovary: tamarins

\section{Introduction}

Ageing of the female reproductive system has been well studied in humans and a number of rodent species (vom Saal \& Finch, 1988). Reproductive senescence in women is characterized primarily by a depletion of follicles in the ovary, accompanied by decreases in concentrations of ovarian steroids (oestradiol, oestrone and progesterone) and increases in gonadotrophin concentrations (Sherman et al., 1978). Irregular patterns of menstrual cyclicity are common in premenopausal women and may reflect significant alterations in hypothalamic-pituitary function (vom Saal \& Finch, 1988). In contrast to women, in various rodent species reproductive senescence is characterized by extensive involvement of all parts of the hypothalamic-pituitary-ovarian axis; the ovary is not necessarily the primary mediator (vom Saal \& Finch, 1988). Graham et al. (1979) state that there are no data to indicate that the endocrinological changes characteristic of perimenopausal women are paralleled in rodents or other non-primate species. 
Reproductive ageing has been examined in a few Old World primate species. Old macaque monkeys (20-25 years old) frequently display marked cycle irregularity and, at menopause, display endocrine and ovarian changes similar to those in menopausal women (Hodgen et al., 1977; Graham et al., 1979; Dierschke, 1985; vom Saal \& Finch, 1988). Old chimpanzees also display menopause, including cessation of menstruation, limited numbers of ovarian follicles and increased concentrations of gonadotrophins (Graham, 1979; Gould et al., 1981); this phenomenon is more poorly defined in this species because of limited availability of old females.

Little is known about age-related reproductive changes in New World primates. New World primates are similar to Old World species in displaying an ovarian cycle that is longer than that of rodents; the cycle is divided into a period of follicular development, culminating in a rise in oestradiol, followed by a surge in luteinizing hormone $(\mathrm{LH})$ and ovulation. Ovulation is followed by a luteal phase during which progesterone concentrations increase (Hearn, 1983; Knobil \& Hotchkiss, 1988). Significant concentrations of oestrone appear to be produced by the corpus luteum in New World as well as Old World primates (Peters \& McNatty, 1980; Dixson, 1983; Nagle $\&$ Denari, 1983). New World primates differ from Old World species in the concentrations of circulating ovarian steroids; concentrations of oestrone and progesterone are 6-20 times higher than in Old World species during the follicular and luteal phases (Dixson, 1983; Hearn, 1983; Nagle \& Denari, 1983; Knobil \& Hotchkiss, 1988). New World species frequently display the persistent presence of luteinized cells (interstitial glands) in the ovary throughout the ovarian cycle (Guraya, 1968; Hertig et al., 1976; Tardif, 1985; Noll et al., 1987).

This report describes some endocrine and ovarian features of reproductive senescence in two species of tamarin: the cotton-top tamarin (Saguinus oedipus) and the saddle-backed tamarin (Saguinus fuscicollis). Tamarins are small (350-600 g), South American primates, belonging to the family Callitrichidae. Tamarins routinely produce twin offspring. The size and temperament of tamarins makes daily blood collection difficult, therefore measurement of urinary hormones is the most commonly used method of assessing ovarian function in these species (Brand, 1981; Epple \& Katz, 1983; French et al., 1983; Hodges \& Eastman, 1984; Ziegler et al., 1987a). In contrast to the common marmoset, in which changes in blood and urinary concentrations of ovarian steroids and LH associated with the ovarian cycle are well defined (Hearn, 1983), in tamarins data on the ovarian cycle (Table 1) are generally limited to analyses of urinary oestrogens.

Table 1. Ovarian cycle in tamarins

\begin{tabular}{|c|c|c|c|c|}
\hline \multirow[b]{2}{*}{ Species } & \multicolumn{2}{|c|}{$\begin{array}{l}\text { Cycle length } \\
\text { (days) }\end{array}$} & \multirow{2}{*}{$\begin{array}{l}\text { Hormone } \\
\text { measured }\end{array}$} & \multirow[b]{2}{*}{ Reference } \\
\hline & Mean & Range & & \\
\hline \multirow[t]{2}{*}{ Saguinus oedipus } & $22 \cdot 7$ & $19-25$ & $\begin{array}{l}\text { Total urinary } \\
\text { oestrogens }\end{array}$ & Brand, 1981 \\
\hline & $23 \cdot 6$ & $18--31$ & Urinary oestrone & French et al., 1983 \\
\hline \multirow[t]{2}{*}{ S. fuscicollis } & 18 & - & $\begin{array}{l}\text { Total urinary } \\
\text { oestrogens, } \\
\text { Urinary luteinizing } \\
\text { hormone }\end{array}$ & Hodges et al., 1981 \\
\hline & $17 \cdot 3$ & $15-21$ & $\begin{array}{l}\text { Plasma oestradiol, } \\
\text { Urinary oestradiol }\end{array}$ & Epple \& Katz, 1983 \\
\hline
\end{tabular}

The maximum captive life-span of tamarins is 20-22 years (Bowden \& Jones, 1979). Epple \& Katz (1983) report that two wild-caught, saddle-backed tamarin ( $S$. fuscicollis) females were still reproducing at estimated ages of 13 and 15 years. The oldest female of known age to produce offspring in the Oak Ridge colony was 13.9 years old. However, signs of reduced fertility have been 
observed in females over 12 years old, including reduced litter size and lack of observable pregnancies in some females (Tardif \& Clapp, 1984). In an examination of age-related differences in the ovaries of tamarins from 2 to $>15$ years old (Tardif, 1985), there was a marked decline in the number of primary follicles with advancing age. Age and the number of primary follicles available had little effect on the number of follicles recruited into the preantral population, but there were significantly fewer large preantral and antral follicles with increasing age and more atretic antral follicles. Luteal-like masses were found in all ovaries examined and their size and appearance was unrelated to age. Similar results are reported by Noll et al. (1987). The present study represents the first examination of hormonal changes associated with ageing in these species.

\section{Materials and Methods}

\section{Animals}

The subjects of this study were individually housed female tamarins. Because of potential social influences on ovarian cyclicity in these species (Epple \& Katz, 1984; French et al., 1984; Ziegler et al., 1987b), each animal was housed next to an adult male of the same species with visual, olfactory, and auditory contact and no female was housed adjacent to a female conspecific. Details on the housing and management of the colony are given in Clapp \& Tardif (1985). The study population of $S$. oedipus consisted of four old (13-17 years old at the beginning of the study) and two young adult females (3-5 years old). The experimental design was to follow all females for $2-3$ years, but, because of age-related deaths, all females were not included throughout the study. Two of the older females were examined for one sampling period, one for two periods and one for three periods. The study population of $S$. fuscicallis consisted of two old females (15-17 years old) and four, 3-5-year-old females. Each control female was examined for one sampling period and each older female for three periods (see Table 2).

All older females, with one exception, were known to be multiparous. The oldest age of parturition for females in this sample was 11.5 years. Female 4771 (see Table 2) was born in a colony at a different facility and her breeding history is unknown. All young females, were nulliparous except 4815 , which had three deliveries before her use in this study.

\section{Sample collection}

Sampling periods of $6-8$ weeks were used, with one sampling period per year. Blood $(0.5-0.7 \mathrm{ml})$ was collected 23 days a week and urine was collected 4-6 days a week. Samples were centrifuged at $3000 \mathrm{~g}$ for $15 \mathrm{~min}$, then stored in separate aliquots for each assay, at $-70^{\circ} \mathrm{C}$. Urine aliquots for use in the $\mathrm{LH}$ assay were stored with glycerol $(0.52 \mathrm{~mol} / \mathrm{l})$.

\section{Hormone measurements}

We examined plasma and urinary measures of ovarian steroids (plasma progesterone and urinary oestrone glucuronide) and a urinary measure of LH. Progesterone and oestrone are of probable luteal origin in New World primates (Dixson, 1983; Nagle \& Denari, 1983; Ziegler et al., 1987a). These hormones were selected to provide information for assessment of occurrence of ovulation, cycle length and cycle regularity and for comparison with previous studies on these species (Brand, 1981; Epple \& Katz, 1983; French et al., 1983; Hodges \& Eastman, 1984; Ziegler et at.. 1987a), given that the data on ovarian cycles of tamarins are generally limited to urinary oestrogens.

Plasma progesterone. This hormone was measured by radioimmunoassay using antiprogesterone-11-bovineserum-albumin (BSA) plasma (provided by G. Niswender, Colorado State University). The assay methods have been previously described and validated for $S$. oedipus (Tardif, 1984). For the present study, serial dilutions of plasma from S. fuscicollis were analysed and were parallel to the standard curve. Sensitivity of the assay was $0.025 \mathrm{ng} / \mathrm{tube}$ and $50100 \mu$ of plasma was extracted and assayed for each sample. Intra- and interassay coefficients of variation for duplicate pool samples were 2.5 and $11.0 \%$, respectively $(n=15)$.

Urinary oestrone conjugates. Concentrations were measured by a direct radioimmunoassay. This technique uses rabbit anti-oestrone-3-glucuronide-BSA (Dr Samarajeewa, London) antibody at a 1:18000 dilution and 6,7${ }^{3}[\mathrm{H}]$ oestrone-3-glucuronide (sp. act. $53 \mathrm{Ci} / \mathrm{mmol}$, Dr Samarajeewa, London) as trace at 10000 c.p.m. Details of assay procedure and validation for $S$. oedipus have been reported (Ziegler et al., 1987b). Five serial dilutions of urine from one female of $S$. fuscicollis were parallel to the standard curve. Assay sensitivity was $13 \mathrm{pg} /$ tube and intra- and interassay coefficients of variation for triplicate pool samples were 2.46 and $6.0 \%$, respectively $(n=6)$. Extensive data in $S$. oedipus suggest that urinary oestrone conjugates are the major oestrogen metabolites with clear ovarian cyclicity (Ziegler et al., 1987a, 1989). It is unclear whether oestrogen metabolism is similar in $S$. fuscicollis, but limited data suggest that urinary oestrone excretion may not reflect ovarian cyclicity (Epple \& Katz, 1983). Urine samples from 
one young cycling female of $S$. fuscicollis were analysed for oestradiol and oestrone concentration by hydrolyzing, extracting and separating the steroids with column chromatography (French et al., 1983). Oestrone and urinary oestrone conjugates followed the same pattern during cycling $(r=0.78, n=21)$, but oestradiol showed consistent basal concentrations except for a surge that occurred before the sustained oestrone increase, indicating that urinary oestradiol may reflect physiological function in $S$. fuscicollis better than oestrone. All females of $S$. fuscicollis were monitored for urinary oestrone conjugates for comparison with $S$. oedipus.

Luteinizing hormone. Urinary LH was measured by two radioimmunoassays because of depletion of antibody for the first assay system. The first method used rabbit anti-ovine $\mathrm{LH}$, rat ${ }^{125} \mathrm{I}$ - $\mathrm{LH}$ trace and rhesus monkey reference preparation. The methods have been reported for $S$. oedipus (Ziegler et al., 1987a). Assay sensitivity was $25 \mathrm{ng} / \mathrm{ml}$. Intra- and interassay coefficients of variation of duplicate pool samples were $4 \cdot 3$ and $15 \cdot 6 \%$, respectively $(n=10$ ). The second method used ovine LH $\beta$-subunit antibody, iodinated human chorionic gonadotrophin and purified urinary rhesus monkey chorionic gonadotrophin for the reference preparation. Details of the methods have been reported generally (Hodgen et al., 1974) and specifically for use in S. oedipus (Ziegler et al., 1987a). Assay sensitivity was $0.19 \mu \mathrm{l} /$ tube and intra- and interassay coefficients of variation of duplicate pool samples were 3.77 and $5.7 \%$, respectively $(n=2)$. These assays correlated well, $r=0.95(n=32, P<0.001)$. Both species showed parallelism to the standard curve with serial dilutions of urine. A correction factor was used to compare results from the two assay systems.

All urinary hormone concentrations were divided by measured creatinine for each sample by the method of Tietz (1976). Preliminary information suggests that tamarins are similar to the common marmoset (Hodges \& Eastman, 1984) and the owl monkey (Dixson, 1983) in that concentrations of plasma progesterone and urinary oestrone conjugates follow similar profiles of high luteal concentrations in normally cycling females.

\section{Oestrous cycle}

The patterns of changes in progesterone, oestrone conjugates and LH were used to define the following features of the cycle:

(1) Ovulation was defined by an identifiable surge in urinary LH or a progesterone concentration of $>20 \mathrm{ng} / \mathrm{ml}$ for at least 8 days (Hearn, 1983; Tardif, 1984). The most reliable indicator of ovulation was an $\mathrm{LH}$ surge followed by an increase in progesterone concentration, but, because urine samples were not collected every day, LH surges were not always detected. For this reason, change in progesterone concentration alone was used as a secondary indicator of ovulation. Surges in LH and progesterone increases were generally accompanied by a rise in oestrone conjugates, but baseline concentrations of oestrone conjugates were highly variable between individuals.

(2) Cycle length was defined by one or more of the following: the number of days from one LH surge to the next; the number of days from one rise in progesterone or oestrone conjugates to the next. If LH surges were detected, estimates of cycle length were considered reliable to within one day, but, if estimates were made using cyclicity of progesterone or oestrone conjugates, cycle length was only considered accurate to within \pm 2 days.

(3) Cycle regularity was examined by comparing the incidence of prolonged or shortened cycles (see Table 1 for range of cycle lengths) and the occurrence of anovulatory periods as defined by (i) lack of an LH surge for 20 days when samples were collected daily or (ii) progesterone concentrations of $<20 \mathrm{ng} / \mathrm{ml}$ for $>12$ days.

\section{Evaluation of data}

The occurrence of ovulation, cycle lengths and cycle regularity were compared in the young and older females for each species. Because few subjects were involved and the number of sampling periods per subject was unequal, these data are initially presented and discussed for each subject, without statistical analyses. After this description, a MannWhitney test was used to compare the cycle lengths of young versus old females. Because differences in hormone patterns relative to age during anovulatory periods were noted a posteriori, an analysis of variance followed by Scheffe's tests (Gill, 1978) was used to determine any significant difference in progesterone concentrations of young versus old anovulatory tamarins.

For five of the tamarins (one young and four old), ovaries were taken at necropsy after the animals died of natural causes. Endocrine data were not available for the period immediately preceding death in these subjects. The ovaries were processed and serially sectioned for light microscopy as described by Tardif (1985). The number of normal and total (normal + atretic) antral follicles and the presence of luteinized interstitial cells was scored for each subject. Because the tissues were fixed at different times after death, normal antral follicles were defined conservatively as those in which less than half of the granulosa cells were pycnotic (Tardif, 1985). These data were compared with previous reports on ovarian ageing in these species (Tardif, 1985; Noll et al, 1987).

\section{Results}

Because there were species differences in the relation between concentrations of progesterone, oestrone conjugates and LH over time, data for each species are presented separately. 
In S. oedipus female no. 4424, urinary LH surges occurred at about the time plasma progesterone rose, indicating that ovulation had occurred (Fig. 1a). Concentrations of urinary oestrone conjugates and plasma progesterone were closely correlated, with a lag of 2 days explained by the metabolism and excretion rates of the oestrone $(r=0.715, P<0.01)$ (Ziegler et al., 1989). Plasma progesterone measures were only available for a 4-week period for S. fuscicollis (Fig. 2a); plasma progesterone and urinary oestrone conjugates were not so closely correlated in this species $(r=0 \cdot 460, \mathrm{NS})$ but the number of samples available for comparison was small $(n=5)$; LH surges were not detected. Generally, immunoreactive LH was lower in S. fuscicollis than in S. oedipus.
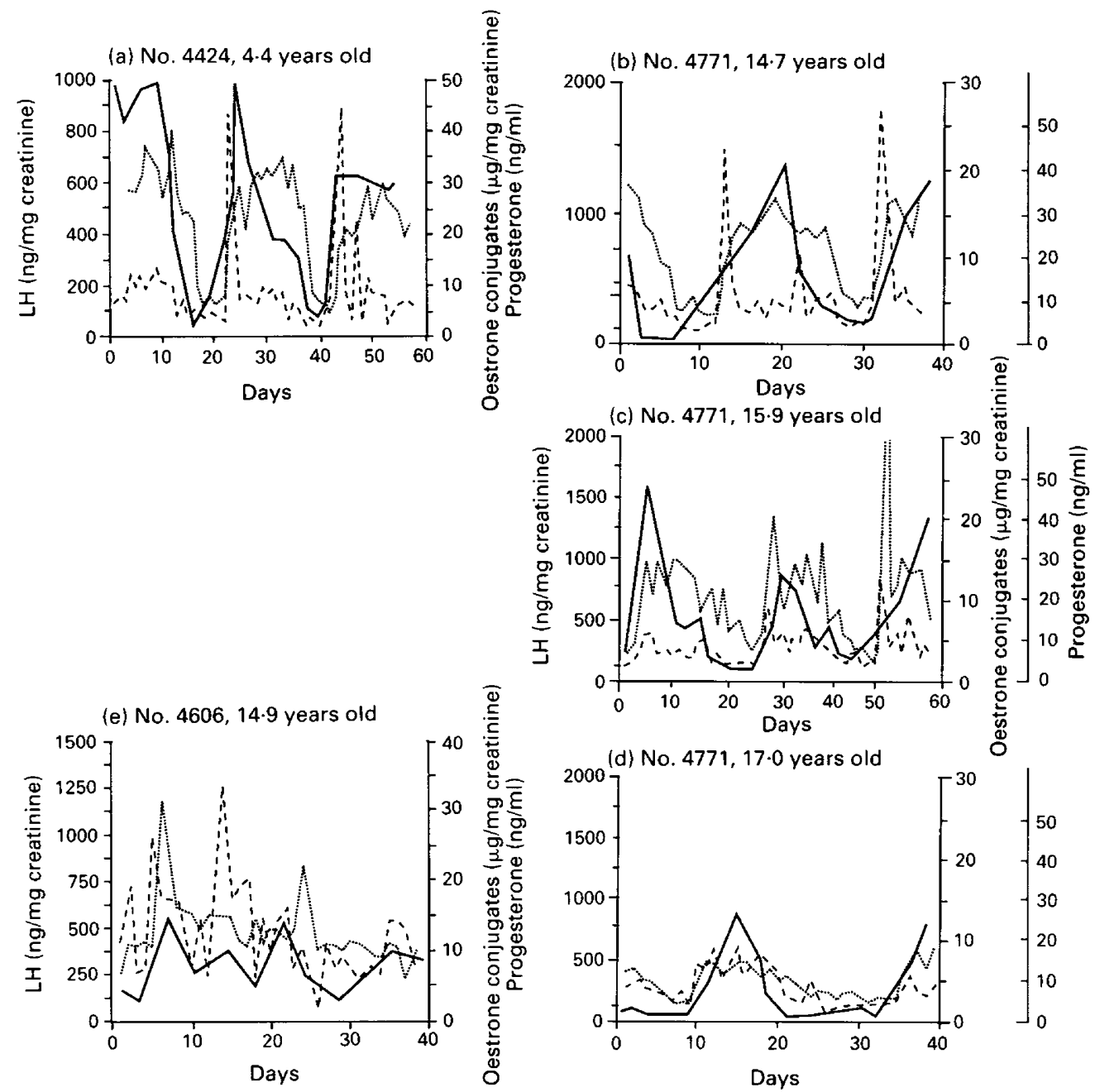

Fig. 1. Patterns of change in urinary oestrone-conjugates (---), urinary luteinizing hormone $(\mathrm{LH}, \cdots)$ and plasma progesterone (-) in (a) a young adult, (b), (c) and (d) an old female examined over 3 years and, (e) an old, anovulatory female of Saguinus oedipus.

There was evidence for ovulation in all periods for young, adult control females in both species (Table 2). Ovulation occurred in six of seven periods for older S. oedipus and two of six periods for older S. fuscicollis. 
(a) No. $4842,5.0$ years old

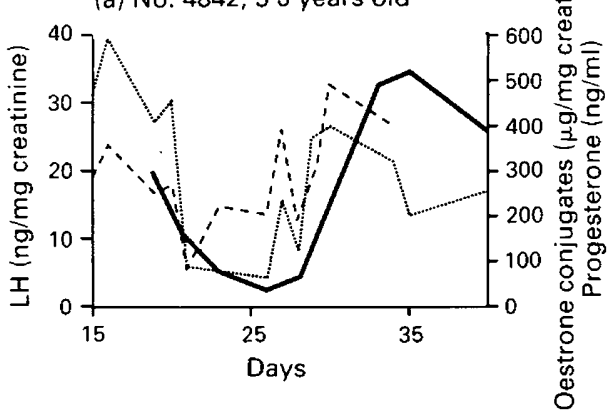

(e) No. $2020,18.7$ years old

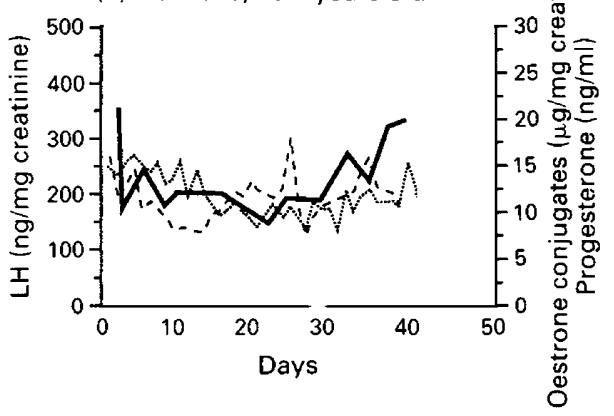

(b) No. 2024, 15.3 years old

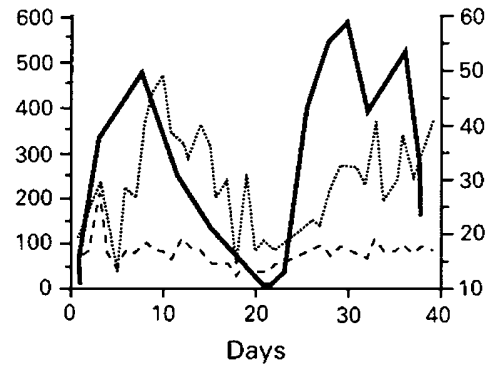

(c) No. 2024, 16.6 years old

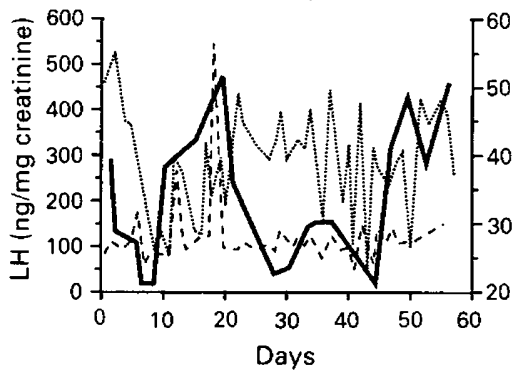

(d) No. $2024,17.7$ years old

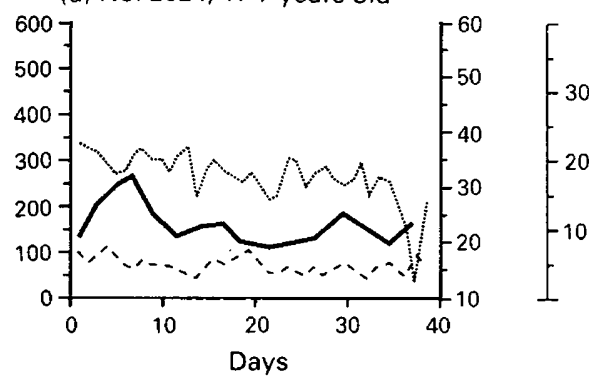

Fig. 2. Patterns of change in urinary oestrone-conjugates (-- ), urinary luteinizing hormone $(\mathrm{LH}, \cdots)$, and plasma progesterone (-) in (a) a young adult female, (b), (c) and (d) an old female examined over 3 years and (e) an old anovulatory female of Saguinus fuscicollis. Note different units of LH measure, reflecting use of different reference preparations (see Materials and Methods).

Cycle length was defined by days between LH peaks in two cycles, by days between one $\mathrm{LH}$ peak and the next rise in progesterone and oestrone conjugates in three cycles and by days between increases in progesterone and oestrone conjugates in nine cycles. For this reason, cycle lengths may generally be considered reliable only to within 2 days. The median cycle length did not differ between young and old $S$. oedipus (Mann-Whitney $U=19, P=0 \cdot 59$ ). Two old $(4604,4606)$ females displayed cycles longer than the typical cycle. One old S. fuscicollis ovulated (2024); her cycle length was within the range of those displayed by young adult females in one year and was prolonged in the second year.

Regular, cyclical changes in progesterone and oestrone conjugates were displayed in three of four periods for young $S$. oedipus, but in only three of seven periods for old S. oedipus. One young female displayed a 25 -day anovulatory phase during which progesterone was undetectable, but 
Table 2. Features of ovarian cyclicity in young and old tamarins

\begin{tabular}{lccccc}
\hline Species & $\begin{array}{c}\text { Identification } \\
\text { no. }\end{array}$ & $\begin{array}{c}\text { Age } \\
\text { (years) }\end{array}$ & Ovulation & $\begin{array}{c}\text { Regular } \\
\text { cycle }\end{array}$ & $\begin{array}{c}\text { Cycle length } \\
\text { (days) }\end{array}$ \\
\hline Saguinus oedipus & 4364 & $3 \cdot 6$ & Yes & Yes & 21 \\
& 4424 & $4 \cdot 7$ & Yes & No & 42 \\
& $4 \cdot 4$ & Yes & Yes & 20 \\
& 4604 & $13 \cdot 5$ & Yes & Yes & 23 \\
& 1095 & $14 \cdot 1$ & Yes & No & 27 \\
& 4606 & $14 \cdot 9$ & Yes & Yes & 23 \\
& 4771 & $16 \cdot 2$ & Yes & No & -38 \\
& & $14 \cdot 7$ & Yes & Yes & 20 \\
& & $15 \cdot 9$ & Yes & Yes & 24 \\
& & $17 \cdot 0$ & Yes & No & 24 \\
& 4683 & $3 \cdot 3$ & Yes & No & - \\
& 4841 & $5 \cdot 0$ & Yes & Yes & 21 \\
& 4842 & $5 \cdot 0$ & Yes & Yes & 26 \\
& 4815 & $5 \cdot 5$ & Yes & Yes & 21 \\
& 2024 & $15 \cdot 3$ & Yes & Yes & 21 \\
& $16 \cdot 6$ & Yes & No & 35 \\
& & $17 \cdot 7$ & No & - & - \\
& 2020 & $15 \cdot 7$ & No & - & - \\
& $17 \cdot 7$ & No & - & - \\
& & $18 \cdot 7$ & No & - & - \\
& & & & & \\
& & & & &
\end{tabular}

Table 3. Concentrations of plasma progesterone and urinary oestrone conjugates in young and old anovulatory female tamarins

\begin{tabular}{|c|c|c|c|c|}
\hline Species & $\begin{array}{l}\text { Identification } \\
\text { no. }\end{array}$ & $\begin{array}{c}\text { Age } \\
\text { (years) }\end{array}$ & $\begin{array}{l}\text { Progesterone } \\
\quad(\mathrm{ng} / \mathrm{ml})\end{array}$ & $\begin{array}{l}\text { Oestrone conjugates } \\
\text { ( } \mu \mathrm{g} / \mathrm{mg} \text { creatinine })\end{array}$ \\
\hline Saguinus oedipus & $\begin{array}{l}4364 \\
4606 \\
4771\end{array}$ & $\begin{array}{r}4.7 \\
14.9 \\
17.0\end{array}$ & $\begin{array}{r}4 \cdot 1 \pm 1.4 \\
* 8.0 \pm 3.6 \\
4 \cdot 8 \pm 2.9\end{array}$ & $\begin{array}{r}25 \cdot 6 \pm 6 \cdot 3 \\
12 \cdot 7 \pm 4 \cdot 5 \\
4 \cdot 1 \pm 1 \cdot 2\end{array}$ \\
\hline S. fuscicollis & $\begin{array}{l}4683 \\
2024 \\
\\
2020\end{array}$ & $\begin{array}{r}3 \cdot 3 \\
16 \cdot 6 \\
17 \cdot 7 \\
15 \cdot 7 \\
16 \cdot 7 \\
18 \cdot 7\end{array}$ & $\begin{array}{r}2.7 \pm 1.1 \\
* 8.9 \pm 3.7 \\
* 15.2 \pm 2.7 \\
* 11.9 \pm 5.9 \\
* 9.2 \pm 3.7 \\
* 13.9 \pm 3.3\end{array}$ & $\begin{array}{r}0.8 \pm 1.4 \\
39.0 \pm 6.6 \\
26.6 \pm 5.7 \\
7.5 \pm 3.7 \\
13.6 \pm 5.8 \\
11.7 \pm 2.2\end{array}$ \\
\hline
\end{tabular}

*Differ significantly $(P<0.05)$ from mean of young, conspecific.

Values are means \pm SD for each subject/sampling period.

concentrations of oestrone conjugates were high $(17-30 \mu \mathrm{g} / \mathrm{mg}$ creatinine). This period was preceded and followed by increases in progesterone indicative of a regular luteal phase. Irregularities in cycling in old females were different, in that they frequently displayed prolonged periods of moderate concentrations of progesterone and increases in oestrone conjugates. In $S$. fuscicollis, irregularities in cyclicity in one young female were characterized by very low concentrations of progesterone and oestrone conjugates. As in $S$. oedipus, old anovulatory females differed from young females in displaying moderate concentrations of progesterone $(8-19 \mathrm{ng} / \mathrm{ml})$ and oestrone conjugates $(5-50 \mu \mathrm{g} / \mathrm{mg}$ creatinine). The two young, anovulatory females had significantly lower progesterone concentratons than all but one old anovulatory female (Table 3). Concentrations of 
Table 4. Incidence of normal antral follicles in selected tamarins

\begin{tabular}{lcccc}
\hline $\begin{array}{l}\text { Identification } \\
\text { no. }\end{array}$ & $\begin{array}{c}\text { Age at death } \\
\text { (years) }\end{array}$ & $\begin{array}{c}\text { No. of } \\
\text { antral follicles } \\
\text { Normal }\end{array}$ & Total & Reference \\
\hline $\begin{array}{l}\text { Saguinus oedipus } \\
4364\end{array}$ & & & & \\
4771 & $5 \cdot 9$ & 15 & 25 & Present study \\
4606 & $18 \cdot 2$ & 4 & 8 & Present study \\
S. fuscicollis & $16 \cdot 3$ & 0 & 5 & Present study \\
2024 & & & & \\
2020 & $18 \cdot 1$ & 0 & 0 & Present study \\
& $20 \cdot 4$ & 0 & 0 & Present study \\
& $2 \cdot 0-5 \cdot 4$ & $14 \cdot 5^{*}$ & $28^{*}$ & Tardif, 1985 \\
& $6 \cdot 9-10 \cdot 2$ & 7 & $19 \cdot 9$ & Tardif, 1985 \\
& $12 \cdot 9->15 \cdot 9$ & $1 \cdot 5$ & $4 \cdot 0$ & Tardif, 1985 \\
& $1 \cdot 2-8 \cdot 0$ & $10 \cdot 3^{*}$ & $34^{*}$ & Noll et al., 1987 \\
& $8 \cdot 0-13 \cdot 0$ & 0 & 26 & Noll et al., 1987 \\
& $13 \cdot 0->15 \cdot 0$ & 1 & 12 & Noll et al., 1987 \\
\hline
\end{tabular}

*Numbers are medians.

oestrone conjugates were highly variable among individuals (Table 3); mean concentrations did not display a particular pattern in anovulatory females, relative to species or age.

One old female (4771) of $S$. oedipus displayed normal ovulatory cycles at 14.7 years and 15.9 years (Fig. 1b). At 17.0 years of age, she ovulated, but displayed a short luteal phase ( $\approx 7$ days) followed by a prolonged anovulatory period. Basal LH concentrations increased in the third year and concentrations of oestrone conjugates were lower. One old female (2024) of S. fuscicollis displayed a normal ovulatory cycle at $15 \cdot 3$ years, apparent ovulation with an aberrant pattern of cycling at 16.6 years and no ovulation with moderate concentrations of progesterone and oestrone conjugates at $17 \cdot 7$ years (Fig. 2 b).

In two old females who were anovulatory (4606 of S. oedipus and 2020 of S. fuscicollis) steroid concentrations were measurable, but not clearly cyclical, and $\mathrm{LH}$ concentrations were greater than in young females (Figs 1 and 2).

There was no consistent relation between mean basal urinary LH concentration (all samples excluding the LH peak) and age. In S. oedipus, one old female (4606) significantly higher mean LH concentration than all young females $(466.9$ versus $198.6 \mathrm{ng} / \mathrm{\mu g}$ creatinine; $P<0.001$ for a Scheffe's comparison). In $S$. fuscicollis, $\mathrm{LH}$ concentration displayed high interindividual variation with no pattern relative to age or cyclicity.

As in previous studies, older females tended to have few $(<1000)$ follicles (Table 4$)$; no females had ovaries totally devoid of follicles. Three of the four older females had no normal antral follicles, but all older females had luteinized interstitial tissue (interstitial glands) in both ovaries.

\section{Discussion}

This is the first study to examine age-related effects on ovulatory cycling in a New World primate. The results indicate that female tamarins can continue to ovulate up to at least 17 years of age, which is about $77-85 \%$ of their known maximum life-span in captivity. In this respect, tamarins are similar to Old World primates and different from humans. No non-human primate appears to display the prolonged phase of age-related anovulation (up to $50 \%$ of maximum life-span) that humans do. 
However, there were age-related effects on ovarian cyclicity in the tamarins in this study, including apparent cessation of ovulation in the two oldest females. While ovulation occurred in eight of 14 sampling periods (five of six animals), in only four of 14 periods (three of six animals) were the ovarian cycles regular. In general, the females over 17 years of age were either anovulatory or displayed aberrant cycles. These results are similar to those in macaques and chimpanzees. In Old World Primates and women, changes in follicle-stimulating hormone (FSH) associated with age are usually more pronounced than changes in LH. Although it might then be more informative to examine ageing effects on FSH, there is no established assay for callitrichid FSH.

Older anovulatory tamarins displayed measurable concentrations of both plasma progesterone and urinary oestrone conjugates (hormones of probable luteal origin in New World primates). Anovulatory periods are not uncommon for primates in general, but increased steroids during anovulation are. Older anovulatory Old World primates and humans generally display very low concentrations of ovarian steroids. The young tamarins that displayed anovulatory periods in the present study had low or undetectable concentrations of progesterone or progesterone and oestrone conjugates. Even in the socially mediated reproductive suppression that is common in tamarins (Epple \& Katz, 1984; French et al., 1984; Ziegler et al., 1987b), steroid concentrations remain lower than for cyclic females. The older females in the present study displayed consistently measurable concentrations of progesterone $(8-19 \mathrm{ng} / \mathrm{ml})$ and oestrone conjugates $(5-50 \mu \mathrm{g} / \mathrm{mg}$ creatinine $)$. When subsequent mating of two of these older anovulatory females occurred, anovulation continued with measurable steroid concentrations. This indicates that anovulation was not due to social environment and that these females were not under socially mediated reproductive suppression.

It could be argued that the moderate concentrations of progesterone and oestrone observed in older females is adrenal in origin. In a study of effects of ovariectomy in S. fuscicollis (Epple \& Katz, 1983), plasma progesterone dropped to $<1 \mathrm{ng} / \mathrm{ml}$ in ovariectomized females, but plasma oestrone was similar in normal and ovariectomized females. These results suggest that adrenal production of oestrone may account for the high interindividual variation seen in the concentrations of this hormone in S. fuscicollis. However, the progesterone is probably of ovarian origin. In $S$. oedipus, $41 \%$ of oestradiol is excreted as oestrone (Ziegler et al., 1989); therefore urinary oestrone excretion reflects production of both oestradiol and oestrone.

These results support the view that the interstitial gland in old, anovulatory tamarins is steroidogenic. Noll et al. (1987) found, in a histological study of ovarian development and ageing, that luteal masses in old tamarins ( $>15$ years) stained positively for $3 \beta$-hydroxysteroid dehydrogenase, further suggesting that the cells were steroidogenic. The presence of functional, steroidogenic luteal cells in older ovaries that are not experiencing regular follicular development and ovulation would distinguish the course of ovarian ageing in tamarins from that observed in Old World primates and humans. The lack of an obvious increase in LH in old anovulatory females may be related to this continued steroid production. It would be of interest to determine whether this phenomenon occurs in other New World species displaying persistent luteinization of the ovary, such as the owl monkey (Hertig et al., 1976) and the cebus monkey (Nagle \& Denari, 1983). Also of interest would be a comparison of concentrations of oestradiol in blood of old New World primates versus Old World species. If, as the histological data suggest, follicular development is minimal in old tamarins, we would predict low concentrations of oestradiol (a hormone of probable follicular origin) in contrast to the moderate concentrations of oestrone and progesterone. Unfortunately, we were unable to collect enough serial samples to determine blood concentrations of follicular oestradiol in addition to progesterone in these animals.

In summary, old females of $S$. oedipus and $S$. fuscicollis can be reproductive. This study indicated that ovulation occurred up to 17 years of age, but there were age-related effects which consisted of reduced ovulation or cessation of cycling, aberrant cycles and some increases in urinary $\mathrm{LH}$. Old anovulatory females have measurable concentrations of steroids, which is uncommon in Old World and human primates studied and may be due to the active interstitial gland that occurs in tamarins of all ages after puberty. 
This work was supported by NIH grant RR02022, NIMH grant MH 35-215 and NIH grant RR-00167 (Wisc. Reg. Primate Research Ctr). The technical assistance of K. Hyde, G. Scheffler, F. Wegner and D. Witter is gratefully acknowledged. The Marmoset Research Center is an AAALAC-accredited facility.

\section{References}

Bowden, D.M. \& Jones, M.L. (1979) Aging research in nonhuman primates. In Aging in Nonhuman Primates, pp. 1-13. Ed. D. M. Bowden. Van Nostrand, Reinhold, NY.

Brand, H.M. (1981) Urinary oestrogen excretion in female cotton-topped tamarin (Saguinus oedipus oedipus). Journal of Reproduction \& Fertility $\mathbf{6 2}$, $467-473$.

Clapp, N.K. \& Tardif, S.D. (1985) Marmoset husbandry and nutrition. Digestive Diseases \& Sciences 30, 17S-23S.

Dierschke, D. (1985) Temperature changes suggestive of hot flushes in rhesus monkeys: preliminary observations. Journal of Medical Primatology 14, 271-280.

Dixson, A.F. (1983) The owl monkey (Aotus trivirgatus). In Reproduction in New World Primates, pp. 69-114. Ed. J. P. Hearn. MPT Press, Lancaster.

Epple, G. \& Katz, Y. (1983) The saddle back tamarin and other tamarins. In Reproduction in New World Primates, pp. 115-148. Ed. J. P. Hearn. MPT Press, Lancaster.

Epple, G. \& Katz, Y. (1984) Social influences on estrogen excretion and ovarian cyclicity in saddle back tamarins (Saguinus fuscicollis), American Journal of Primatology 6, 215-228.

French, J.A., Abbott, D.H., Scheffler, G., Robinson, J.A. \& Goy, R.W. (1983) Cyclic excretion of urinary oestrogens in female tamarins (Saguinus oedipus). Journal of Reproduction \& Fertility 68, 177-184.

French, J.A., Abbott, D.H. \& Snowdon, C.T. (1984) The effect of social environment on estrogen secretion, scent marking, and sociosexual behavior in tamarins (Saguinus oedipus). American Journal of Primatology 6, $155-167$.

Gill, J. (1978) Design and Analysis of Experiments in the Animal and Medical Sciences, vol. I. Iowa State University Press, Ames.

Gould, K.G., Flint, M. \& Graham, C.E. (1981) Chimpanzee reproductive senescence: a possible model for evolution of the menopause. Maturitas 3, 157-166.

Graham, C.E. (1979) Reproductive function in aged female chimpanzees. American Journal of Physical Anthropology 50, 291-300.

Graham, C.E., Kling, O.R. \& Steiner, R.A. (1979) Reproductive senescence in female nonhuman primates. In Aging in Nonhuman Primates, pp. 183-202. Ed. D. M. Bowden. Van Nostrand, Reinhold, NY.

Guraya, S.S. (1968) Histophysiology and histochemistry of interstitial gland tissue in the ovaries of nonpregnant marmosets. Acta Anatomica 70, 623-640.

Hearn, J.P. (1983) The common marmoset (Callithrix jacchus). In Reproduction in New World Primates, pp. 181-216. Ed. J. P. Hearn. MTP Press, Lancaster.

Hertig, A.T., Barton, B.R. \& Mackey, J.J. (1976) The female genital tract of the owl monkey (Aotus trivirgatus) with special reference to the ovary. Laboratory Animal Science 26, 1041-1067.

Hodgen, G.D., Tullner, W.W., Vaitukaitis, J.L., Ward, D.N. \& Ross, G.T. (1974) Specific radioimmunoassay of chorionic gonadotropin during implantation for rhesus monkeys. Journal of Clinical Endocrinology and Metabolism 39, 457-464.

Hodgen, G.D., Goodman, A.L., O'Connor, A. \& Johnson, D.K. (1977) Menopause in rhesus monkeys: model for study of disorders in the human climacteric. American Journal of Obstetrics and Gynecology 127, 581-584.

Hodges, J.K. \& Eastman, S.A.K. (1984) Monitoring ovarian function in marmosets and tamarins by the measurement of urinary estrogen metabolites. American Journal of Primatology 6, 187-197.

Hodges, J.K., Gulick, B.A. \& Czekala, N.M. (1981) Comparison of urinary oestrogen excretion in South American primates. Journal of Reproduction \& Fertility 61, 83-90.

Knobil, E. \& Hotchkiss, J. (1988) The menstrual cycle and its neuroendocrine control. In The Physiology of Reproduction, vol. 2, pp. 1971-1994. Eds E. Knobil \& J. D. Neill. Raven Press, NY.

Nagle, C.A. \& Denari, J.H. (1983) The cebus monkey (Cebus apella). In Reproduction in New World Primates, pp. 39-68. Ed. J. P. Hearn. MTP Press, Lancaster.

Noll, S., Kuderling, I. \& Epple, G. (1987) Postnatal development of the ovary in female saddle back tamarins, (Saguinus fuscicollis). International Journal of Primatology 8, 484.

Peters, H. \& McNatty, K.P. (1980) In The Ovary, pp. 56-58. University of California Press, Berkeley.

Sherman, B.M., West, J.H. \& Korenman, S.G. (1978) The menopausal transition: analysis of $\mathrm{LH}, \mathrm{FSH}$, estradiol and progesterone concentrations during menstrual cycles of older women. Journal of Clinical Endocrinology \& Metabolism 42, 629-636.

Tardif, S.D. (1984) Social influences in sexual maturation of female Saguinus oedipus oedipus. American Journal of Primatology 6, 199-209.

Tardif, S.D. (1985) Histologic evidence for age-related differences in ovarian function in tamarins (Saguinus sp., Primates), Biology of Reproduction 33, 993-1000.

Tardif, S.D. \& Clapp, N.K. (1984) Reproductive longevity in tamarin females (Saguinus sp.). Laboratory Animal Science 34, 504.

Tietz, N.W. (1976) Fundamentals of Clinical Chemistry. Ed. W. B. Saunders, Philadelphia.

vom Saal, F.S. \& Finch, C.E. (1988) Reproductive senescence: phenomena and mechanisms in mammals and selected vertebrates. In The Physiology of Reproduction, vol. 2, pp. 2351-2413. Eds E. Knobil \& J. D. Neill. Raven Press, NY. 
Ziegler, T.E., Bridson, W.E., Snowdon, C.T. \& Eman, S. (1987a) Urinary gonadotropin and estrogen excretion during the postpartum estrus, conception and pregnancy in the cotton-top tamarin (Saguinus oedipus oedipus). American Journal of Primatology 12, $127-140$.

Ziegler, T.E., Savage, A., Scheffler, G. \& Snowdon, C.T. (1987b) The endocrinology of puberty and reproductive functioning in female cotton-top tamarins
(Saguinus oedipus) under varying social conditions. Biology of Reproduction 37, 618-627.

Ziegler, T.E., Sholl, S.A., Scheffier, G., Haggerty, M.A. \& Lasley, B.L. (1989) Excretion of estrone, estradiol and progesterone in the urine and feces of the female cotton-top tamarin (Saguinus oedipus oedipus). American Journal of Primatology 17, 185-195.

Received 2 January 1991 